\title{
DEVELOPMENT AND APPLICATION OF METHODS OF INTERNAL INSPECTION OF DISTRICT HEATING NETWORKS
}

\author{
I.I. MURTAZIN ${ }^{1}$, M.V. KOZHEVNIKOV ${ }^{2}$ \& E.M. STARIKOV ${ }^{2}$ \\ ${ }^{1}$ JSC 'Ekaterinburg Heat Distribution Company', Russia. \\ ${ }^{2}$ Department of Energy and Industrial Management Systems, Ural Federal University, Russia.
}

\begin{abstract}
The reliability of heat supply in cities is largely determined by the actual condition of pipelines, for example, corrosive and erosive wear. Comparative analysis of methodological approaches to assessing the technical condition of district heating networks shows that the most innovative and effective approach is internal pipe inspection using non-destructive magnetic testing. The article presents the results of research tests of the method in the context of its use for maintenance and retrofitting of the heating infrastructure in Yekaterinburg, a Russian city with a complex topology of utility networks and extremely uneven tear and wear on some sections of the networks. The authors describe the technical and economic peculiarities of using internal pipe inspection methods at various stages of testing and formulate qualitative and quantitative criteria for assessing the effectiveness of the method being presented. Recommendations have been suggested for the optimum application of the method by heat network operators, especially those operating and servicing district heating systems.

Keywords: heating networks, inspection, overhaul, magnetic method, pipeline, pressure testing, technical condition, economic efficiency.
\end{abstract}

\section{INTRODUCTION}

The reliability and efficiency of heating systems in cities, especially those with district heating networks, depends a lot on the actual technical state of pipes and, in particular, the degree of corrosion and erosion $[1,2]$.

The problem of assessing the actual state of heat pipes and their remaining service life, that is, the time during which it is possible to transfer the heat carrier to the consumer without an emergency outage, has existed since heat networks came into existence [3]. At various times, heat network operators tested in practice common and little-known methods of fault detection and non-destructive (NDT) control, such as ultrasonic, magnetic, electromagnetic tools, acoustic emission, vortex flow metering, radiography, and television inspections. The tests showed that none of the methods guarantees accurate identification of faults in underground pipes [4].

As the problem has been raised in the academic and professional communities, designers of diagnostic equipment are encouraged to improve the existing NDT control methods $[5,6]$.

This study aims to assess the economic and technical efficiency of innovative methods of internal inspection of heating networks and then to give them a test run on heating facilities in Yekaterinburg - a Russian city with a particularly complex topology of utility networks and unevenly developed heat supply systems.

Along with other issues, the study describes an approach to addressing the tasks of internal pipe inspection and subsequent planning of replacement works on faulty sections of pipelines and considers the efficiency of executing the works in-house as opposed to hiring a contractor. 


\section{METHODOLOGICAL PECULIARITIES OF INSPECTION AND REFURBISHMENT OF HEATING PIPELINES}

There are a number of basic methodological approaches to assessing the efficiency of heating pipeline upgrade projects.

The first one envisages the ranking of pipe section replacement projects by payback period $[7,8]$. A standard set of formulas and technical and economic coefficients is used (operating expenses and capital expenditures; standard, excessive, and actual heat losses; undersupply of energy; mean downtime). The approach can be used as part of any energy asset management strategy (preventive maintenance, time-based maintenance), as well as in more advanced strategies such as condition-based maintenance $[9,10]$.

Replacing pipelines in heating networks is usually very expensive [11]. Early detection of faults, the use of the newest inspection robots, and replacement of the most corroded sections could considerably extend the service life of networks, reduce the number of abrupt disruption incidents, and cut costs. This makes it advisable to combine the first approach with the priority method that includes the risk-based ranking of facilities and is only utilized in advanced asset management strategies $[12,13]$.

The case of the Moscow United Energy Company (MOEK) [14] is studied here. In order to improve reliability, the company designed and introduced a system for heat network pipeline repair planning and execution. The system consists of three phases.

Phase 1. Each section of the heat network is assigned a weighted rank score.

The technical state of pipelines is assessed and the ranking of network sections is done by heat pipeline inspection specialists, who use certification, operation, and analytical data and calculate the integral score (from 0 to 100):

$$
I S=\sum_{1}^{i} W_{i} \times A_{i}
$$

where $I S$ is the integral ranking score, $W_{i}$ is the weight of criterion $A_{i}$, and is assessment by criterion $i$.

The following criteria are used to rank the sections of the heating network: service duration, section redundancy rate, number of connected buildings, heat supply is ensured to high-priority consumers in case an area of the pipe is damaged, inspection results, failure rate, and the damaged area of the pipe is replaced.

Phase II. A list of heating networks with high integral scores is compiled. The lower the score, the better the condition of the pipe section. The sturdiest networks have a score of about 0; networks with the score of 50-70 are included in the inspection schedule; networks with a score exceeding 70 get an unscheduled inspection; preventive works are scheduled or plans are made in the investment program for pipeline replacement.

Phase III. A scheduled inspection and repair program for heat networks is formed (Fig. 1).

The biggest factor in the final score is the data obtained through physical control methods and testing of heating networks. For that purpose, the MOEK carries out comprehensive technical inspection of pipelines and annual hydraulic testing.

Comprehensive technical inspection implies the use of a combination of diagnostic methods employing modern devices and tools for efficiency and performance:

- visual and dimensional testing;

- ultrasonic thickness measurement, flaw detection, screening of pipes;

- detection and analysis of possible damage for control in inspection pits; 


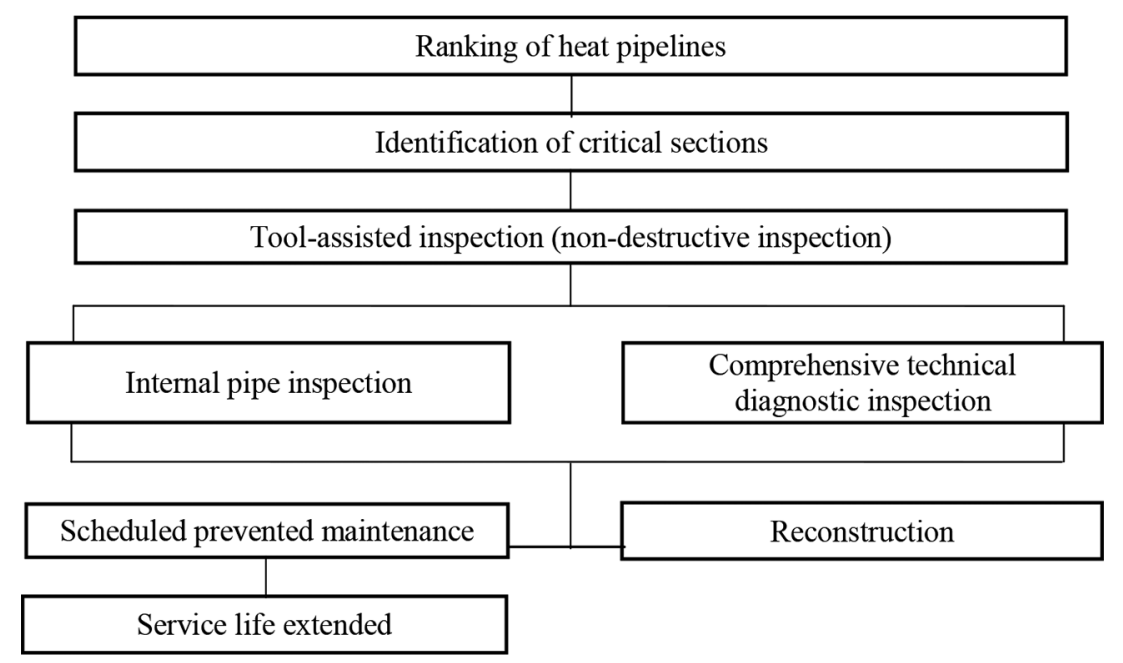

Figure 1: Algorithm for planning and carrying out repair works on the heating networks operated by the MOEK.

- measurement of stress concentration (metal magnetic memory);

- acoustic tomography; and

- measurement of the hardness of the base metal and of electric potential [15, 16].

Comprehensive inspection can detect only up to $60 \%$ of critical defects because in most cases, the actual thickness of the pipe is determined by measurements obtained in the course of repairs and mandatory scheduled pit inspections. In that case, however, only certain areas of pipelines are analyzed, which does not yield accurate information as to the degree of corrosion and its potential hazardous impact along the entire section of the network.

On the other hand, even if accurate information is available about alterations in the pipeline wall thickness along the entire section, subsequent strength calculations use projected parameters of the technical condition of in-line elements, such as sliding and fixed supports and the expansion joints that are also susceptible to corrosion. This leads to the actual hazard degree of corrosion intervals in pipes being imprecisely determined.

More complete information on the thickness of the pipe wall along the entire length of the section can be obtained by using defect detection devices for internal pipe inspection that are fitted with ultrasonic modules or permanent magnet thickness meters [17].

Of all the methods and technologies used for pipe inspection today, the most accurate results are obtained by the use of internal inspection technology [18]. The technology is capable of delivering information that is sufficient for plausibly determining the remaining service life (detection and measurement of corrosion damage parameters, location of defects, description of the actual topology of the pipeline network).

The companies that sell equipment for internal pipe inspection are listed in Table 1.

Most of the companies use acoustic (ultrasonic, EMAT, acoustic resonance testing) and magnetic flux leakage (MFL) NDT methods. Such equipment is successfully used for inspecting gas and oil pipelines that have no corrosion deposits on the inner surface [5, 19]. However, during their use time, the inner surface of heating pipes gets covered with a layer of corrosion products that can be as thick as $15 \mathrm{~mm}$ (in some cases, up to $30 \mathrm{~mm}$ ). This makes it impossible to obtain plausible results by using conventional pipe control methods as: 
Table 1: Companies in the internal tube inspection market.

\begin{tabular}{|c|c|c|}
\hline Company & Website & Non-destructive control method \\
\hline $\begin{array}{l}\text { Applus RTD, The } \\
\text { Netherlands }\end{array}$ & $\begin{array}{l}\text { https://www.applus.com/ } \\
\text { global/en/what-we-do/ser- } \\
\text { vices/ndt }\end{array}$ & $\begin{array}{l}\text { Ultrasonic immersion pulse echo } \\
\text { technique }\end{array}$ \\
\hline TesTex, Inc., USA & https://testex-ndt.com & $\begin{array}{l}\text { Ultrasonic immersion pulse echo tech- } \\
\text { nique with a rotating mirror }\end{array}$ \\
\hline $\begin{array}{l}\text { Breivoll Inspection } \\
\text { Technologies AS, } \\
\text { Norway }\end{array}$ & $\begin{array}{l}\text { https://breivoll.eu/diagnos- } \\
\text { tics/pipeline-inspection/ }\end{array}$ & Acoustic resonance technology \\
\hline $\begin{array}{l}\text { The } \\
\text { ROSEN Group, } \\
\text { The Netherlands }\end{array}$ & $\begin{array}{l}\text { http://www.rosen-group. } \\
\text { com/global/solutions/pipe- } \\
\text { line-systems.html }\end{array}$ & $\begin{array}{l}\text { MFL testing } \\
\text { EMAT (ultrasonic testing method that } \\
\text { uses electromagnetic acoustic trans- } \\
\text { ducers) }\end{array}$ \\
\hline NPC VTD, Russia & $\begin{array}{l}\text { http://www.npcvtd.ru/en/ } \\
\text { services/vnutritrubnaya- } \\
\text { diagnostika/ / }\end{array}$ & $\begin{array}{l}\text { MFL } \\
\text { EMAT }\end{array}$ \\
\hline $\begin{array}{l}\text { Transneft Diascan, } \\
\text { Russia }\end{array}$ & $\begin{array}{l}\text { http://en.diascan.transneft. } \\
\text { ru/klientam/vnytritrybnaya- } \\
\text { diagnostika/?re=en }\end{array}$ & $\begin{array}{l}\text { MFL } \\
\text { Ultrasonic immersion pulse echo } \\
\text { technique }\end{array}$ \\
\hline Diakont, Russia & http://www.diakont.com & $\begin{array}{l}\text { EMAT } \\
\text { AMF technique }\end{array}$ \\
\hline
\end{tabular}

AMF, alternating magnetic field; MFL, magnetic flux leakage.

- acoustic inspection techniques require surface preparation and

- corrosion products make the use of MFL ineffective - sensitivity drops significantly if the wall thickness exceeds $15 \mathrm{~mm}$ and corrosion deposits could cause false flux leakage calls.

By contrast, the alternating magnetic field (AMF) technique has considerable advantages thanks to a larger thickness range and its capability of handling corrosion buildups. The methods of internal heating pipe inspection are compared in Table 2.

The AMF technique is, therefore, the optimum method of internal inspection of heating networks with internal corrosion buildups.

\section{TESTING OF INNOVATIVE TECHNOLOGIES OF INTERNAL PIPE INSPECTION}

We shall describe the results of field tests of a number of innovative internal pipe inspection technologies in district heating networks in Ekaterinburg (other spellings of the city name which could be found in publications - Yekaterinburg or Jekaterinburg) - a Russian city with a population exceeding 1.5 million. The city has an extremely expansive main heating system with hundreds of damages registered annually (Fig. 2). With submain heat and hot water lines taken into account, the number of damages could reach thousands. All pipes are made of steel.

External corrosion is the most common (up to 80\%) cause of ruptures in heat pipes. External corrosion occurs when metal comes in contact with water because the pipeline trench is 
Table 2: Comparison of internal pipe inspection methods.

\begin{tabular}{|c|c|c|c|}
\hline Characteristics & AMF & MFL & Ultrasonics \\
\hline $\begin{array}{l}\text { Accurate information obtained through a layer of corro- } \\
\text { sion products and slime on the inner surface of pipe }\end{array}$ & + & - & - \\
\hline $\begin{array}{l}\text { Guaranteed detection of areas of pitting corrosion under } \\
\text { a layer of corrosion products }\end{array}$ & + & - & - \\
\hline $\begin{array}{l}\text { Penetration defects are identified through a layer of cor- } \\
\text { rosion products }\end{array}$ & + & - & - \\
\hline No acoustic coupling is needed & + & + & - \\
\hline $\begin{array}{l}\text { Simplicity of automation (scanning, data harvesting, } \\
\text { control data interpretation) }\end{array}$ & + & + & - \\
\hline $\begin{array}{l}\text { Thickness measurements can be taken regardless of the } \\
\text { defect profile }\end{array}$ & + & - & - \\
\hline Precision of thickness measurements in defect area & + & - & $\begin{array}{l}+ \\
\text { (only if sur- } \\
\text { face prepa- } \\
\text { ration is } \\
\text { conducted) }\end{array}$ \\
\hline Uninterrupted scanning & + & + & + \\
\hline
\end{tabular}

AMF, alternating magnetic field; MFL, magnetic flux leakage.

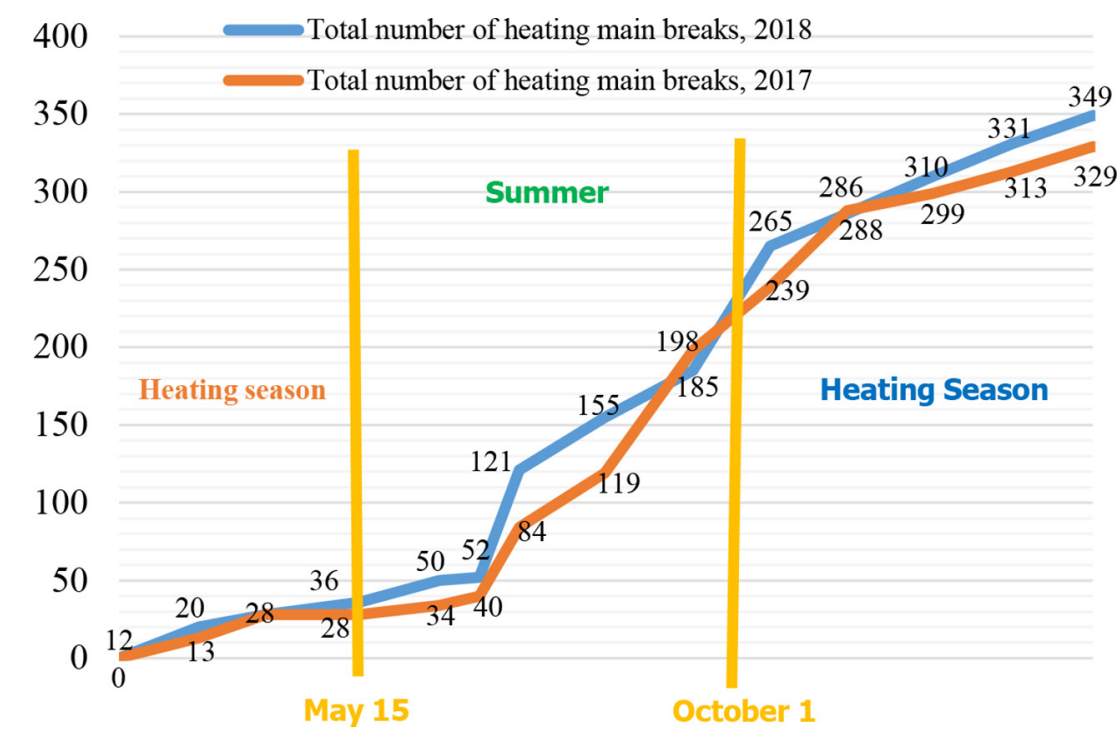

Figure 2: Timeline of heating main breaks in Ekaterinburg.

regularly or constantly flooded with ground water or surface water due to the absence of drainage, insufficient height and strength of sliding supports, the use of ineffective anti-corrosive coating and insulation with high water absorption, poor sealing of trenches, and the 
lack of ventilation in trenches and heat chambers. The external corrosion of pipes is also caused by stray currents (leaking from DC-electrified municipal transport and railways, etc.).

Wear in pipelines across the city is uneven. In order to determine how many pipes need replacing annually, it is necessary to compile a repair schedule by analyzing the condition of all pipelines in the network on a yearly basis [20]. Considering the frequency of the occurrence of damages, the priority here is the timely rehabilitation of the most worn-out sections of pipelines.

District heat assets in Yekaterinburg are maintained by the heat transport company Ekaterinburg Heat Grid Company (EHGC). It is one of the largest regional district heating companies in Russia by the size of network. EHGC supplies hot water and heat to 1.5 million domestic consumers. The company maintains 439 central heat distribution stations, $381.1 \mathrm{~km}$ of main heat pipelines, $2284.5 \mathrm{~km}$ of submain and distribution single-pipe pipelines (calculated as the total length of feed and return lines in the system), and 11 pumping stations. Figures 3 and 4 present an overview of EHGC's heat supply zones.

The company has been actively adopting the latest technology for heat pipe inspection. In 2017 and 2018, the company used a remote-controlled robotic inspection system with an alternating magnetic control module.

\subsection{Research testing}

In 2018, the EHGC conducted NDT inspection of underground heat pipelines with a total length of $2374 \mathrm{~km}$. The inspection was carried out using a remote-controlled pipe robot designed and manufactured by Diakont (Fig. 5). The robot was fitted with removable CCTV camera, KTC-4 (Fig. 6), and a magnetic control module, MMK-24 (Fig. 7).

The MMK-24 robot is designed for measuring the thickness of pipeline walls in areas of wall thinning with the diameter of no less than $300 \mathrm{~mm}$ and for detecting defects on the inner and outer surfaces of pipes along with simultaneous automated sweeping inspection applying the AMF technique. As explained in part 2 of the article, the latter is the most optimum method in the described circumstances.

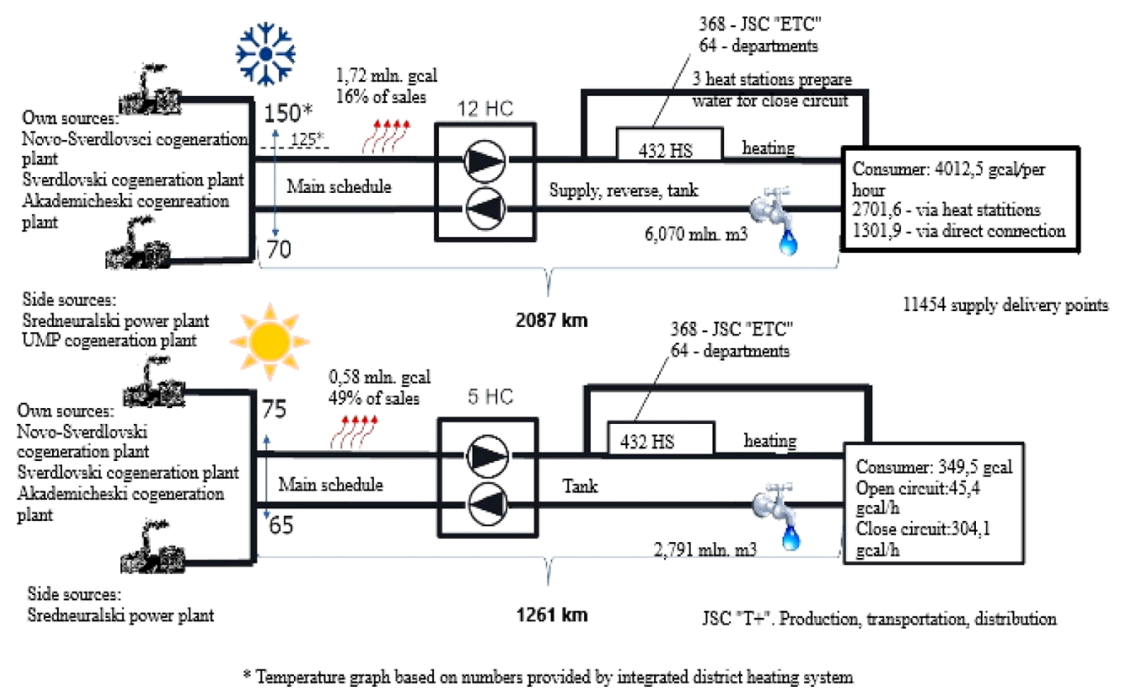

Figure 3: General information about EHGC -operated zone of united district heating network. 


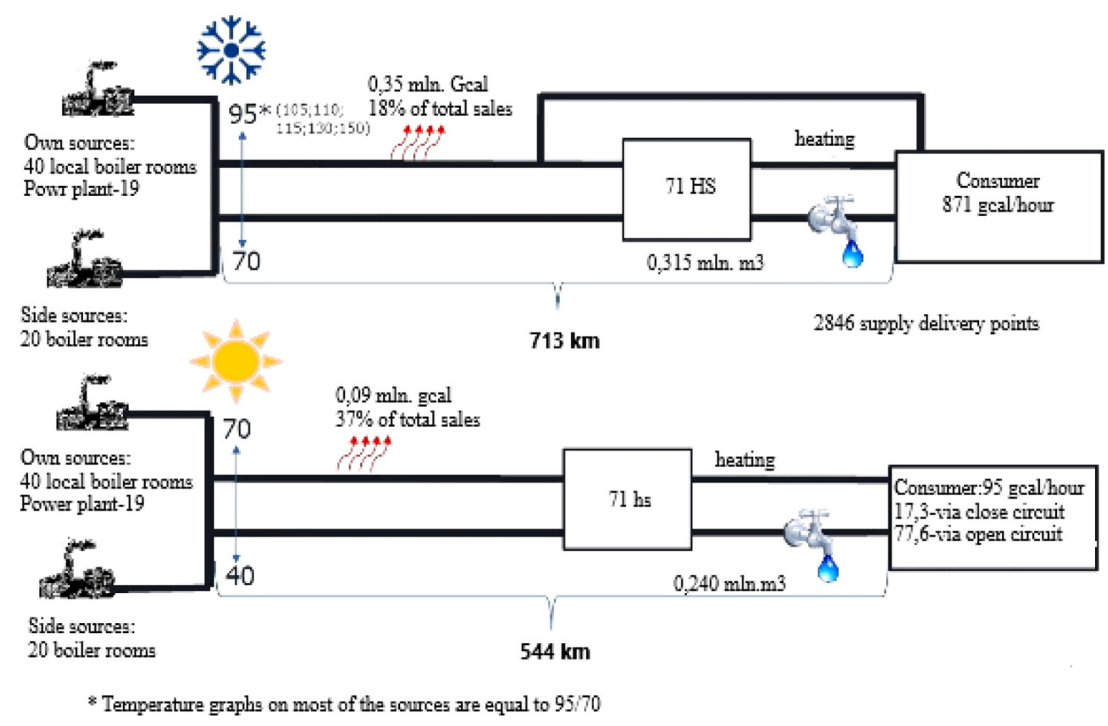

Figure 4: General information about EHGC-operated local sources zone.

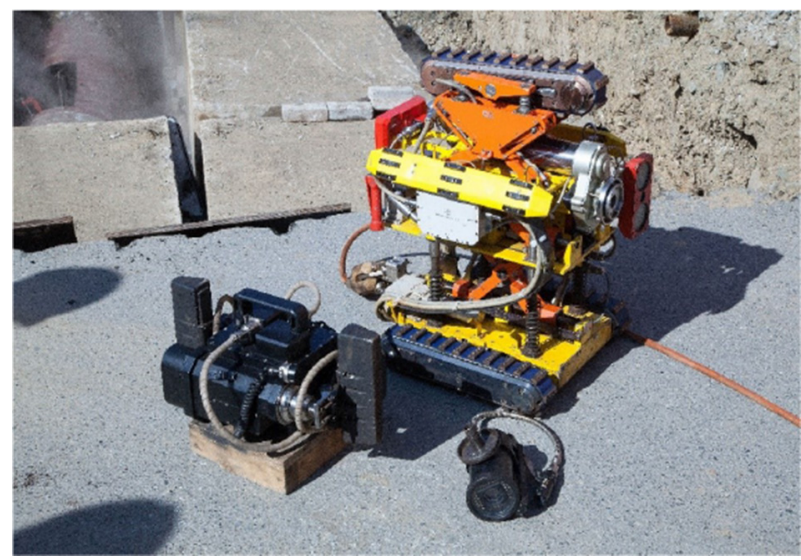

Figure 5: Remotely controlled inspection robot.

The tests aimed to check the effectiveness of pressure testing that was meant to reveal defects in main pipelines as well as to verify the accuracy of internal pipe inspection. The tested item was the delivery pipe of a main heat pipeline network. The testing plan included several stages.

1. Following the internal pipe inspection, information about the location and photographic evidence of the following defects was obtained:

- fouling and foreign objects;

- stub-ins, denting, deformation and ruptures of the base metal, process windows; and

- optically visual defects of circumferential welded joints and edges of process windows (faulty welds, joint displacement).

2. Following the internal pipe inspection, the following information about corrosion damages was presented: 


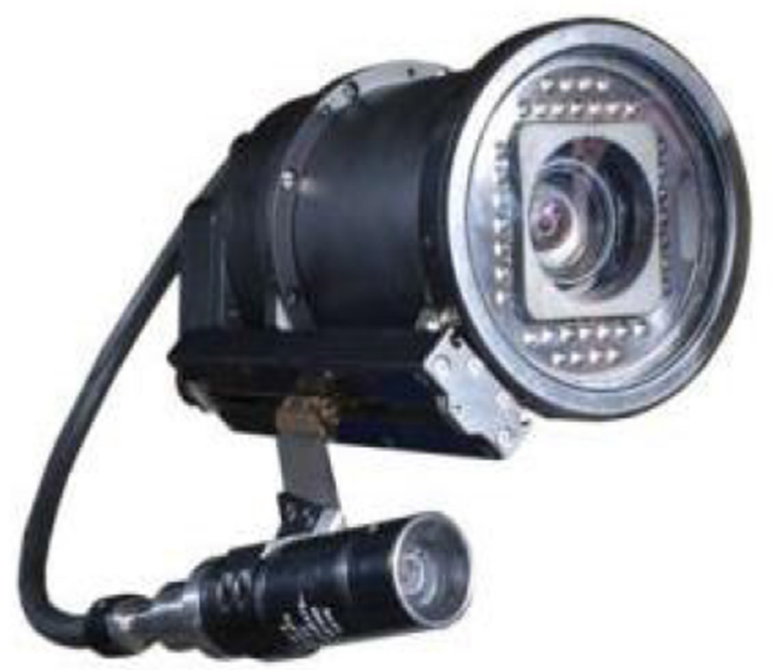

Figure 6: Camera module.

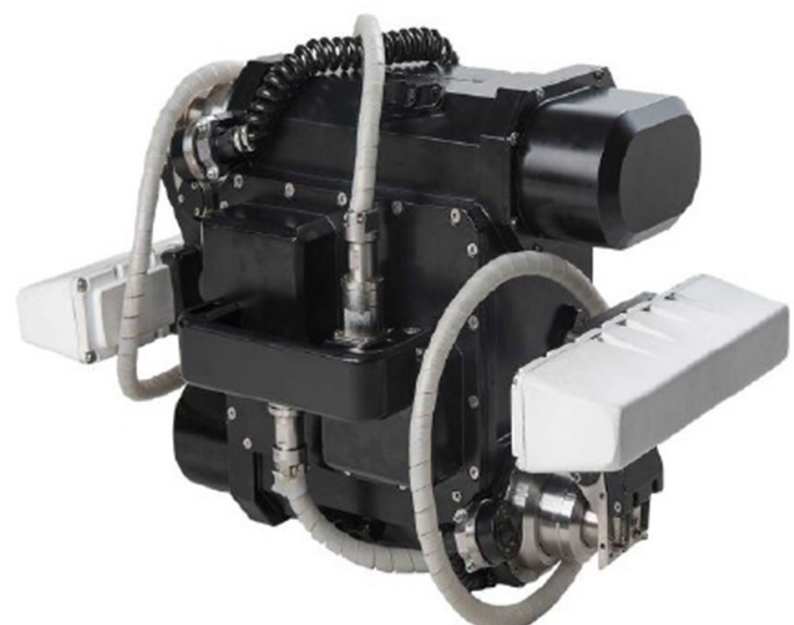

Figure 7: Magnetic control module.

- location of defects in the longitudinal (in relation to the loading point and the start of the element) and circumferential directions;

- geometrical size of the defect area and residual thickness measured in the defect area;

- ranking of the revealed defects by the degree of pipe wear; and

- rehabilitation recommendations for all revealed defects.

3. Plausibility of the inspection findings is verified:

- phase 1 - hydraulic pressure testing is conducted to check the strength and hardness of the defect area and

- phase 2 - supplementary NDT inspection of the chosen areas on the outside of the pipe. 
Table 3: Pressure load on pipe during hydraulic testing.

\begin{tabular}{llll}
\hline Step & Test pressure, MPa & Exposure time, min & Outcome \\
\hline 1 & 0.5 & 5 & Test water volume $2 \mathrm{~m}^{3} / \mathrm{h}$ \\
2 & 1.0 & 5 & Test water volume $9 \mathrm{~m}^{3} / \mathrm{h}$ \\
3 & 1.2 & 5 & Test water volume $5.8 \mathrm{~m}^{3} / \mathrm{h}$ \\
4 & 1.4 & 10 & Test water volume $6.4 \mathrm{~m}^{3} / \mathrm{h}$ \\
& & $\mathbf{3}$ & Pipe withstood pressure test \\
$\mathbf{5}$ & $\mathbf{1 . 4 5}$ & & Pipe destroyed \\
\hline
\end{tabular}

Phase 1. Hydraulic pressure testing is an essential way of preparing district heat networks to the next heating season. It helps detect worn-out sections of pipelines and eliminate defects in time for the start of the heating season to prevent emergency failures therein.

Hydraulic pressure tests were conducted on a section of the delivery pipeline with the length of $916.1 \mathrm{~m}$ under $0.85 \mathrm{MPa}$. The test pattern envisaged that the pressure would increase gradually in steps with an exposure period after each step. The results of the pressure test are summarized in Table 3.

The pipeline was destroyed at $1.45 \mathrm{MPa}$ : the pressure pushed out a $450 \times 450$-mm manhole cover. An examination of the destroyed area revealed that the damage was due to a badly welded joint of the temporary opening patch (Fig. 8). The destroyed area was outside the section that had been subjected to internal pipe inspection.

Phase 2. Among the defect zones selected for additional defect control, some had two defects. The zones were classified as critical, yet they withstood hydraulic pressure testing. The selected defect zones are described in Table 4.

The results of the internal pipe inspection were verified by EHGC specialists, who cut open the defect sections of the pipeline and inspected them visually and using an ultrasonic thickness gauge. Defects, their location, and minimum residual thickness were confirmed in all sections that had been inspected inside the pipe.

For example, defect section No. 34 was found to have penetration corrosion (Fig. 9) that withstood pressure testing at $1.4 \mathrm{MPa}$, thanks to higher strength of the defect section in the

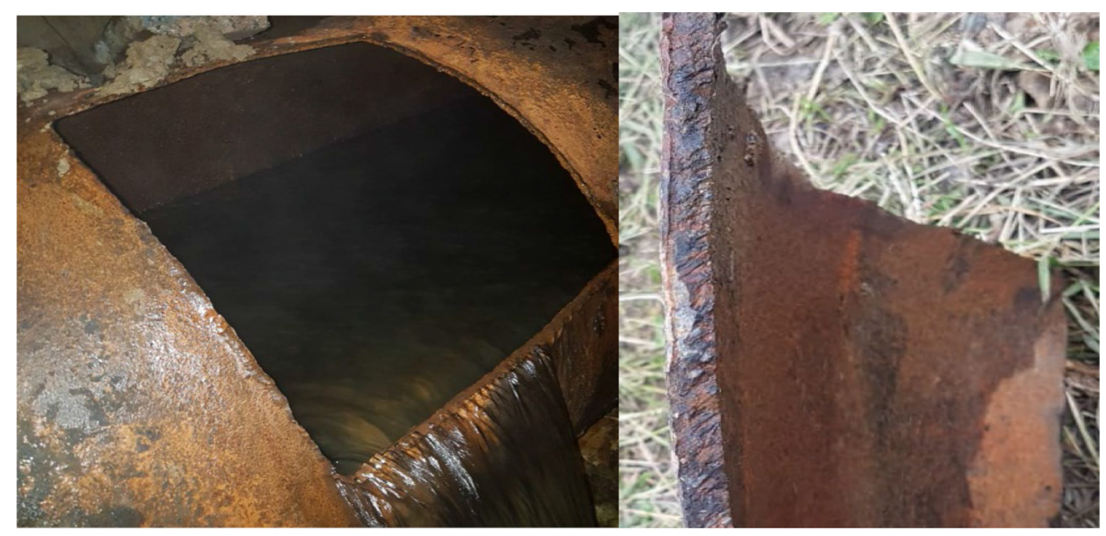

Figure 8: M-37 main pipeline damaged during hydraulic testing. 
Table 4: Selected control results.

\begin{tabular}{lllll}
\hline & $\begin{array}{l}\text { Defect number in } \\
\text { No. }\end{array}$ & Element report & $\begin{array}{l}\text { Residual thickness, } \\
\text { mm }\end{array}$ & $\begin{array}{l}\text { Ranking by internal } \\
\text { pipe inspection result }\end{array}$ \\
\hline 1 & 34 & $2.12-2.13$ & $0.24 \pm 0.07$ & Critical \\
2 & 82 & $3.30-3.31$ & $7.79 \pm 2.33$ & Unhazardous \\
3 & 83 & $3.31-3.32$ & $6.09 \pm 1.82$ & Unhazardous \\
4 & 85 & $3.31-3.32$ & $1.53 \pm 0.46$ & Critical \\
\hline
\end{tabular}

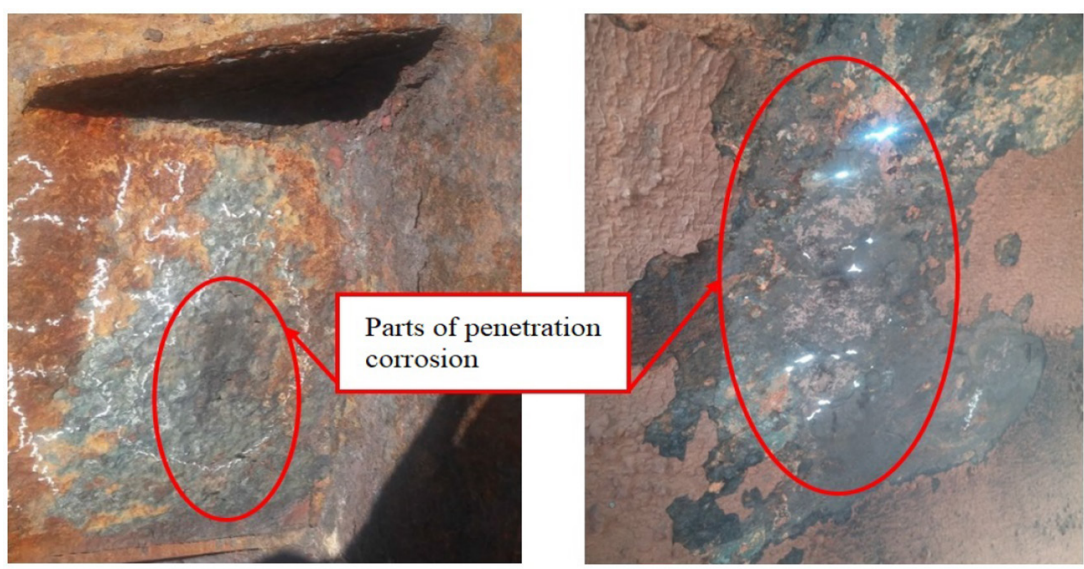

Photo of the exterior of the pipe

Photo taken inside the pipe

Figure 9: Penetration corrosion of defect No. 34, element 2.12-2.13.

ribbing area of the fixed support as well as to a layer of corrosion deposits that had accumulated on the surface of the pipeline throughout its service life.

\subsection{Technology efficiency assessment}

The efficiency of the internal pipe inspection by means of the AMF technique was assessed qualitatively from the perspective of its technological, operational, and defect detection capabilities as well as social and economic performance. The assessment results are presented in Table 5 .

Based on the results of the application of AMF technology for NDT inspection, the following conclusions can be drawn.

1. The AMF technology for NDT inspection and inspection robots are capable of detecting corrosion damage that is the main cause of damage in pipelines.

2. Verification of NDT inspection results shows that various types of corrosion damage can be detected; penetration corrosion can be detected beneath a layer of deposits; the declared technical and measurement characteristics of the magnetic control system have been confirmed.

3. Hydraulic pressure testing showed that it is impossible to detect all critical losses of thickness and ensure safe operation of the tested area by conducting hydraulic testing.

4. The AMF technology for NDT inspection is an effective way of inspecting heat pipelines as: 
Table 5: Qualitative indicators of the efficiency of internal pipe inspection technology.

\begin{tabular}{|c|c|c|}
\hline $\begin{array}{l}\text { Crite- } \\
\text { rion }\end{array}$ & Advantages & Disadvantages \\
\hline $\begin{array}{l}\text { Techno- } \\
\text { logical } \\
\text { issues }\end{array}$ & $\begin{array}{l}\text { Moderate amount of preparatory work } \\
\text { High degree of inspection plausibility, thanks to } \\
\text { uninterrupted inspection and digital data on the } \\
\text { technical condition of all sections } \\
\text { No need to clean the pipe as inspection can be } \\
\text { carried out through a layer of deposits } \\
\text { A fast delivery brief report is available within } 12 \\
\text { h since the completion of inspection }\end{array}$ & $\begin{array}{l}\text { Road traffic might have to } \\
\text { be restricted or a parallel } \\
\text { pipeline will need to be } \\
\text { cut open and drained for } \\
\text { inspection when pipeline } \\
\text { sections that cross motor- } \\
\text { ways are } \\
\text { A coil needs to be applied } \\
\text { for repairing the pipe at the } \\
\text { robot launch point }\end{array}$ \\
\hline $\begin{array}{l}\text { Opera- } \\
\text { tion }\end{array}$ & $\begin{array}{l}\text { Inspection device is operational } 24 / 7 \\
\text { It is possible to inspect irregularly shaped sec- } \\
\text { tions, pipes half-filled with water and at high } \\
\text { temperature and humidity } \\
\text { Control distance of up to } 300 \mathrm{~m} \text { from the launch } \\
\text { point in both directions }\end{array}$ & $\begin{array}{l}\text { Passing through more than } \\
\text { two } 90^{\circ} \text { branches and verti- } \\
\text { cal sections is complicated } \\
\text { Relatively slow inspection } \\
\text { pace - up to } 20 \mathrm{~m} / \mathrm{h}\end{array}$ \\
\hline $\begin{array}{l}\text { Defect } \\
\text { detec- } \\
\text { tion } \\
\text { capabil- } \\
\text { ity }\end{array}$ & $\begin{array}{l}\text { Any kind of corrosion, including penetration } \\
\text { corrosion, is detected on both the internal and } \\
\text { external surfaces of the pipe if the deposit layer } \\
\text { does not exceed } 15 \mathrm{~mm} \\
\text { Inspection reveals various parameters of defects } \\
\text { and predicts the service life of the pipeline and } \\
\text { suggests recommendations as to repair and } \\
\text { maintenance }\end{array}$ & $\begin{array}{l}\text { Only the base metal of } \\
\text { pipes is subjected to con- } \\
\text { trol. Joints and valves are } \\
\text { not inspected } \\
\text { There are short 'dead' } \\
\text { zones at both ends of the } \\
\text { inspected section }\end{array}$ \\
\hline $\begin{array}{l}\text { Social } \\
\text { param- } \\
\text { eters }\end{array}$ & $\begin{array}{l}\text { Technology aims to prevent failures and inci- } \\
\text { dents } \\
\text { Better safety of inspection works - no risk of in- } \\
\text { cidents causing third-party damage and destroy- } \\
\text { ing urban infrastructure }\end{array}$ & - \\
\hline $\begin{array}{l}\text { Eco- } \\
\text { nomic } \\
\text { param- } \\
\text { eters }\end{array}$ & $\begin{array}{l}\text { Repair and rehabilitation costs are decreased } \\
\text { thanks to precise localization of critical corro- } \\
\text { sion defects } \\
\text { No need to spend extra on eliminating the after- } \\
\text { math of ruptures during heating season } \\
\text { Possibility of long-term planning of repair } \\
\text { works, associated resources and materials } \\
\text { Lower risk of causing third-party damage and } \\
\text { ensuing insurance claims }\end{array}$ & $\begin{array}{l}\text { Additional expenditures re- } \\
\text { quired to prepare the target } \\
\text { item to inspection }\end{array}$ \\
\hline
\end{tabular}

- it makes it possible to carry out inspection despite deposits that have accumulated through the pipe service life; 
- it requires minimum preparatory efforts - the time gap between preparation of the tested item and the launch of the robot does not usually exceed $6 \mathrm{~h}$, including the draining of the system and the cutting of temporary openings; and

- it delivers highly accurate inspection results that have been independently verified.

5. The use of the technology makes it possible to objectively assess the technical condition of the inspected sections and helps reduce costs as part of the condition-based maintenance strategy while taking into account the influence of the detected defects on the safe operation of the pipeline.

The following economic efficiency assessment of the project was based upon a scenario that the internal pipe inspection robot is purchased using the company's own resources for year-round use. The calculations assumed the following conditions: the project becomes fully productive as of 2020; planning horizon - through to 2025; and discount rate accepted by the company $-13.46 \%$.

If the project parameters meet the baseline values, the project has the following investment characteristics:

- CAPEX - RUB58.7M (€0.8M),

- NPV - RUB226.44M (€3M) over the forecasting period,

- IRR - $124.49 \%$,

- non-discounted payback period - 1.83 years, and

- discounted payback period -1.95 years.

It has to be noted that during the idling of the inspection robot, additional personnel will be able to handle 100-150 pipe leak reports a year, which could cut the cost of excavating inspection shafts by up to RUB3m (€40,000) a year.

Analysis of the economic efficiency shows that pipeline operators that have acquired a robotic inspection system should be able to conduct internal pipe inspections on $10 \mathrm{~km}$ of pipework annually. That would extend the safe service life of main heat pipelines by around $3 \%$, provided that critical defects are detected and eliminated.

The analysis also shows that the project's current parameters make it economically expedient and can be recommended as the main investment option.

\section{CONCLUSIONS}

Today, pipeline operators widely use internal pipe inspection techniques that enable them to assess the technical condition of buried pipelines without excavation works. Internal pipe inspection techniques are meant to improve the efficiency of underground heat pipeline inspection, to increase the reliability and safety of pipeline operation, to make planning more effective and ensure timely execution of repair and rehabilitation works, to ensure the stability of heat supply and to reduce damage detection costs.

Building upon the analysis of NDT inspection using the AMF technique, it can be recommended that pipeline operators do the following:

1. conduct internal pipe inspection on pipeline sections with an obvious probability of defects (one or two defects per section per year) rather than on worn-out sections;

2. conduct internal pipe inspection on feeder pipelines because the detection of faults during the heating season leads to the draining of the heating network and heating supply is limited to a large number of consumers, which means significant financial and reputational risks; 
3. conduct internal pipe inspection on complex and hard-to-reach sections of the network;

4. conduct a repeat internal pipe inspection of the tested sections 5 years into operation in order to check again the results of the verification of NDT inspection findings and monitor corrosion processes; and

5. make arrangements for internal pipe inspection in-house and extend the capacity of the existing inspection service.

The AMF technique for internal pipe inspection delivers savings in the first year of its use, provided that hydraulic pressure testing does not reveal critical faults. The technique also makes it possible to adjust the investment program and direct funds to sections with stronger wear.

A limitation to the use of the in-pipe inspection techniques described in the article is that the deployment of an internal pipe inspection robot might require excavation. Of course, heat supply networks are equipped with specialized thermal imaging cameras (cameras in branch pipelines, sectionalizing valves, pipe inspection cameras, etc.) that make it possible to install the robot. They can, however, be fitted in unsuitable locations and be of inappropriate size. As a result, an access hole needs to be cut of no less than $600 \times 400 \mathrm{~mm}$ and not more than 1000 $\times 700 \mathrm{~mm}$. This entails the replacement of the section of the pipe following the inspection by open-cut method. Open-cut works must comply with strict safety requirements that are formalized in the Russian legal and regulatory framework.

It needs to be mentioned that the objective of increasing the efficiency of heat supply is not reached exclusively in the realms of inspection and maintenance. In order to increase the reliability of heat networks, comprehensive transformations need to take place as regards the design and operation of heat supply assets. This includes active adoption of modern insulation materials and concrete channel drainage systems that make it possible to considerably decrease thermal losses and risks of defects caused by external corrosion.

In 2019-2020, the EHGC successfully used an in-pipe inspection robot on some of the most complex sections of the city heat supply network in preparation for a winter heating season. Inspection robots are planned to be given wider application in 2 or 3 years. The timing depends on economic and other factors including emergencies such as the COVID-19 pandemic. If the infection situation remains tense, it might be necessary to speed up the transition to robots in order to minimize human involvement in inspection and maintenance works.

\section{ACKNOWLEDGMENT}

The work was supported by Act 211 of the Government of the Russian Federation, contract №. 02.A03.21.0006.

\section{REFERENCES}

[1] Huang, F., Kang, J.-J., Yue, W., Liu, X.-B., Fu, Z.-Q., Zhu, L.-N., She, D.-S., Ma, G.-Z., Wang, H.-D., Liang, J., Weng, W. \& Wang, C.-B., Effect of heat treatment on erosioncorrosion of Fe-based amorphous alloy coating under slurry impingement. Journal of Alloys and Compounds, in press, 2019.

[2] Fan, L., Reis, S.T., Chen, G. \& Koenigstein, M.L., Corrosion resistance of pipeline steel with damaged enamel coating and cathodic protection. Coatings, 8, p. 185, 2018. https://doi.org/10.3390/coatings8050185

[3] Jouhara, H., Chauhan, A., Nannou, T., Almahmoud, S., Delpech, B. \& Wrobel, L.C., Heat pipe based systems - Advances and applications. Energy, 128, pp. 729-754, 2017. https://doi.org/10.1016/j.energy.2017.04.028 
[4] Xu, Q., Feng, J., Liu, L., Zhou, J., Ye, G. \& Chang, C., Analysis of mechanical-fluidthermal performance of heat pipeline system with structural deformation effects. International Journal of Heat and Mass Transfer, 128, pp. 12-23, 2019. https://doi. org/10.1016/j.ijheatmasstransfer.2018.08.122

[5] Carvalho, A.A., Rebello, J.M.A., Souza, M.P.V., Sagrilo, L. \& Soares, S.D., Reliability of non-destructive test techniques in the inspection of pipelines used in the oil industry. International Journal of Pressure Vessels and Piping, 85(11), pp. 745-751, 2008. https://doi.org/10.1016/j.ijpvp.2008.05.001

[6] Barkanov, E.N., Dumitrescu, A. \& Parinov I.A., Non-destructive Testing and Repair of Pipelines, Springer: Cham, 2018. 451 p.

[7] Upgrading the performance of district heating networks. Technical and non-technical approaches. A Handbook, WIP Renewable Energies: Munich, Germany, 2019, https:// www.upgrade-dh.eu/images/Publications\%20and\%20Reports/D2.5_2019-07-02_ Upgrade-DH_Handbook_EN.pdf. Accessed on: 15 Dec. 2019

[8] Kruczek, T., Determination of annual heat losses from heat and steam pipeline networks and economic analysis of their thermomodernisation. Energy, 62, pp. 120-131, 2013. https://doi.org/10.1016/j.energy.2013.08.019

[9] Gitelman, L.D., Kozhevnikov, M.V. \& Kaplin, D.D., Asset management in grid companies using integrated diagnostic devices. International Journal of Energy Production and Management, 4(3), pp. 230-243, 2019. https://doi.org/10.2495/eq-v4-n3-230-243

[10] Baev, I., Dzyuba, A., Solovyeva, I. \& Kuzmina, N., Improving the efficiency of using small-distributed generation systems through mechanisms of demand management for electricity and gas. International Journal of Energy Production and Management, 3(4), pp. 277-291, 2018. https://doi.org/10.2495/eq-v3-n4-277-291

[11] Gudmundsson, O., Thorsen, J.E. \& Zhang, L., Cost analysis of district heating compared to its competing technologies. WIT Transactions on Ecology and The Environment, 176, pp. 107-118, 2013.

[12] Sernhed, K. \& Jönsson, M., Risk management for maintenance of district heating networks. Energy Procedia, 116, pp. 381-393, 2017. https://doi.org/10.1016/j.egypro.2017.05.085

[13] Gitelman L.D., Kozhevnikov M.V. \& Gavrilova T.B., Managing productive assets of energy companies in periods of crisis. In Syngellakis, S., Brebbia, C., eds., Challenges and Solutions in the Russian Energy Sector. Innovation and Discovery in Russian Science and Engineering, Springer: Cham, pp. 55-61, 2018.

[14] Implementing ITU-T International Standards to Shape Smart Sustainable Cities: The Case of Moscow, 2018, https://www.itu.int/dms_pub/itu-t/opb/tut/T-TUT-SSCIOT2018-PDF-E.pdf. Accessed on: 15 Dec. 2019.

[15] Zimmerman, N.A., Dahlquist, E. \& Kyprianidis, K.G., Towards on-line fault detection and diagnostics in district heating systems. Energy Procedia, 105, pp. 1960-1966, 2017. https://doi.org/10.1016/j.egypro.2017.03.567

[16] Miyata, S., Lim, J., Akashi, Y., Kuwahara, Y. \& Tanaka, K., Fault detection and diagnosis for heat source system using convolutional neural network with imaged faulty behavior data. Science and Technology for the Built Environment, 2019, https://www.tandfonline.com/doi/pdf/10.1080/23744731.2019.1651619?needAccess=true. Accessed on: 15 Dec. 2019. 
[17] Ghavamian, A., Mustapha, F., Baharudin, B.H.T. \& Yidris, N., Detection, localisation and assessment of defects in pipes using guided wave techniques: A review. Sensors, 18, p. 4470, 2018.

[18] Safizadeh, M.S. \& Azizzadeh, T., Corrosion detection of internal pipeline using NDT optical inspection system. NDT\&E International, 52, pp. 144-148, 2012. https://doi. org/10.1016/j.ndteint.2012.07.008

[19] Shi, Y., Zhang, C., Li, R., Cai, M. \& Jia, G., Theory and application of magnetic flux leakage pipeline detection. Sensors, 15, pp. 31036-31055, 2015. https://doi. org/10.3390/s151229845

[20] Gitelman, G., Magaril, E., Kozhevnikov, M., Genon, G., Senor, A.M. \& Panepinto, D., Building an eco-effective district heating management system in a city. E3S Web of Conferences, 6, p. 03012, 2016. 